\title{
Studi Evaluasi dan Perencanaan Sistem Drainase Perkotaan di Kecamatan Garum Kabupaten Blitar Provinsi Jawa Timur
}

\author{
Rachmat Ady Gunawan $^{1 *}$, Moch. Sholichin ${ }^{1}$, Dian Chandrasasi ${ }^{1}$ \\ ${ }^{1}$ Jurusan Teknik Pengairan, Fakultas Teknik, Univeristas Brawijaya, \\ Jl. MT. Haryono No. 167, Malang, 65145, Indonesia \\ *Korespondensi Email: Rahmatgunawan0703@gmail.com
}

\begin{abstract}
Garum District, especially in Slorok Village, is a densely populated residential area that has under gone many land use changes. The condition of the land as a green open space has changed its function into a residential and office area. One of the impacts is disasters on direct surface runoff and a decrease in the quantity of water that infiltrates the ground, resulting in flooding during the rainy season, so the need for handling, among others, is rehabilitation of drainage channels and planning of infiltration wells. The calculation results show that there are 37 drainage channels, but there are 7 channels that cannot reduce runoff due to land use changes and the existing drainage cannot be filled. The calculation of the rehabilitation of the dimensions of the canal and the dimensions of the infiltration well is invincible with the existing land, then the dimensions of the infiltration well will be divided by the runoff discharge to see how many wells to be built. The calculation of infiltration wells uses the Sunjoto formula. With the results of the calculation of the dimensions of the infiltration well for a diameter of 1.2 $\mathrm{m}$ and a well depth of $2.4 \mathrm{~m}$.
\end{abstract}

Keywords: Infiltration wells, runoff reduction, urban drainage system.

Abstrak: Kecamatan Garum khususnya di Desa Slorok merupakan daerah pemukiman yang padat penduduk yang telah mengalami banyak perubahan tata guna lahan. Kondisi lahan sebagai ruang terbuka hijau beralih fungsi menjadi kawasan pemukiman dan perkantoran. Salah satu dampaknya adalah meningkatnya aliran permukaan langsung dan menurunnya kuantitas air yang meresap ke dalam tanah, sehingga terjadi banjir pada musim hujan, maka perlunya penanganan antara lain rehabilitasi saluran drainase dan perencanaan sumur resapan. Hasil perhitungan menunjukan bahwa ada 37 saluran drainase, tetapi ada 7 saluran yang tidak bisa mereduksi limpasan yang disebabkan perubahan tata guna lahan dan drainase eksisting yang sudah tidak bisa

*Penulis korespendensi: rahmatgunawan0703@gmail.com 
menampung. Perhitungan rehabilitasi dimensi saluran dan dimensi sumur resapan disesuaikan dengan lahan yang ada, kemudian dimensi sumur resapan akan dibagi debit limpasan untuk mengetahui berapa jumlah sumur yang akan dibuat. Perhitungan sumur resapan menggunakan rumus Sunjoto. Dengan hasil perhitungan dimensi sumur resapan untuk diameternya sebesar 1,2 $\mathrm{m}$ dan kedalaman sumur 2,4 m.

Kata kunci: Limpasan permukaan, sistem drainase perkotaan, sumur resapan.

\section{Pendahuluan}

Kota merupakan tempat bagi banyak orang untuk melakukan berbagai aktivitas, maka untuk menjamin kesehatan dan kenyamanan penduduknya harus ada sanitasi yang memadai, misalnya drainase. Dengan adanya drainase tersebut genangan air hujan dapat disalurkan sehingga banjir dapat dihindari dan tidak akan menimbulkan dampak gangguan kesehatan pada masyarakat serta aktivitas masyarakat tidak akan terganggu [1]. Drainase juga merupakan salah satu fasilitas dasar yang dirancang sebagai sistem guna memenuhi kebutuhan masyarakat dan merupakan komponen penting dalam perencanaan kota (perencanaan infrastruktur khususnya). Secara umum, drainase di definisikan sebagai serangkaian bangunan air yang berfungsi untuk mengurangi dan/atau membuang kelebihan air dari suatu kawasan atau lahan, sehingga lahan dapat difungsikan secara optimal [2].

Faktor human behavior juga memengaruhi tata kelola drainase, Percampuran fungsi drainase yang terjadi akibat penyimpangan perilaku pengelolaan sampah dan limbah serta alih fungsi penggunaan lahan di perkotaan/area permukiman yang padat penduduk dan pusat kegiatan perdagangan/pasar tradisional, sehingga membebani kapasitas normal saluran drainase sehingga harus berfungsi sebagai wadah buangan limpasan air hujan maupun limbah domestik dan sampah padat [6].

\section{Bahan dan Metode}

\subsection{Bahan}

\section{A. Lokasi Studi}

Kecamatan Garum merupakan bagian dari wilayah administratif Kabupaten Blitar yang terletak di bagian utara sungai Brantas. Secara geografis Kecamatan Garum terletak pada koordinat $8^{\circ} 4^{\prime} 18^{\prime \prime} \mathrm{LS}$ dan $112^{\circ} 13^{\prime} 52^{\prime \prime} \mathrm{LU}$.

B. Data yang dibutuhkan

- Data Curah Hujan

- Data dan denah kawasan

- Data penduduk 


\subsection{Metode Penelitian}

Setelah diketahuinya kondisi pada daerah studi, Langkah selanjutnya adalah melakukan pengumpulan data-data yang diperoleh dari instansi terkait sebagai sumber data untuk keperluan studi ini. Adapun data-data yang digunakan adalah sebagai berikut [3]:

\section{Hasil dan Pembahasan}

\subsection{Analisa Hidrologi}

Analisa perhitungan curah hujan merupakan langkah awal yang dapat membantu proses Analisa debit banjir rancangan. Analisahidrologi dalam studi ini diperlukan untukmengetahui berapa besar debit banjir rancangan dengan berbagai kala ulang yang telah ditentukan [4].

\subsubsection{Curah Hujan Harian Maksimum}

Pengertian dari curah hujan harian maksimum adalah jumlah curah hujan $\mathrm{n}$ hari yang paling maksimum terjadi dalam satu tahun, dimana $n$ adalah jumlah hari [5].

\subsubsection{Uji Konsistensi Data Hujan}

Data curah hujan yang sudah ada dari 3 stasiun hujan yang berpengaruh di DAS Slorok perlu dilakukan penyelidikan uji konsistensi data hujan untuk mengetahui apakah satu stasiun hujan konsisten dengan stasiun hujan lain [6]

\subsubsection{Curah Hujan Rancangan}

Curah hujan terbesar tahunan yang mungkin terjadi di suatu daerah dengan kala ulang tertentu, yang dipakai sebagai dasar perhitungan perencanaan suatu dimensi bangunan adalah pengertian dari hujan rancangan maksimum. Ada beberapa metode yang dapat dipakai untuk menganalisa curah hujan rancangan adalah distribusi Gumbel, Log Normal, Log Pearson III, dan lain-lain. Untuk menentukan macam analisa frekuensi, perlu dihitung parameter-parameter statistik seperti koefisien $\mathrm{Cs}, \mathrm{Cv}, \mathrm{Ck}$. Syarat untuk distribusi [7]:

1. Gumbel : $\mathrm{Ck}=5,4$ dan $\mathrm{Cs}=1,14$

2. Log Normal : $\mathrm{Ck}=3$ dan $\mathrm{Cs}=0$

3. Log person III : Ck dan Cs bebas

\subsubsection{Uji Kesesuaian Distribusi}

Ada dua cara yang sering digunakan untuk menguji apakah jenis distribusi hujan rancangan yang dipilih sesuai dengan data yang ada, yaitu uji Chi-Square dan Smirnov Kolmogorov.

\subsection{Intensitas Hujan}

Tingginya curah hujanaper satuan waktu disebut juga dengan intensitas hujan. Rumus Mononobe digunakan untuk mendapatkan intensitas hujan selama waktu konsentrasi. Rumusnya sebagai berikut: [4] 
dengan:

$$
\mathrm{I}=(\mathrm{R} 24 / 24) \times(24 / \mathrm{tc})^{2 / 3} \quad \text { Pers. } 1
$$

I = Intensitas hujan selama waktu konsentrasi ( $\mathrm{mm} / \mathrm{jam})$

$\mathrm{R}_{24}=$ Curah hujan maksimum harian dalam 24 jam $(\mathrm{mm})$

Tc = waktu konsentrasi (jam)

\subsection{Waktu Konsentrasi}

Waktu konsentrasi adalah waktu yang dibutuhkan oleh air hujan yang jatuh untuk mengalir dari titik terjauh sampai titik keluaran air. Besarnya waktu konsentrasi dihitung dengan menggunakan rumus Kirpich berikut: [6].

dengan:

$$
\text { Tc }=0,0195\left[\mathrm{~L}^{\prime} \mathrm{S}^{0,5}\right]^{0,77} \quad \text { Pers. } 2
$$

Tc $=$ waktu konsentrasi $(\mathrm{jam})$

$\mathrm{L}=$ Panjang aliran $(\mathrm{km})$

$\mathrm{S}=$ kemiringan saluran

\subsection{Koefisien Pengaliran}

Untuk menentukan harga koefisien pengaliran suatu daerah yang terdiri dari beberapa jenis tata guna lahan dapat ditentukan dengan mengambil harga rata-rata koefisien pengaliran pada setiap tata guna lahan, yaitu dengan memperhitungkan bobot masingmasing bagian sesuai dengan luas daerah yang diwakili [5].

$$
\begin{array}{rlr}
\mathrm{Cm} & =\frac{C 1 \cdot A 1+C 2 \cdot A 2+\ldots \ldots .+C n \cdot A n}{A 1+A 2+\ldots \ldots \ldots+A n} & \text { Pers. } 3 \\
\mathrm{Cm} & =\frac{\sum_{i=1}^{n} C i \cdot A i}{\sum_{i=1}^{n} A i} & \text { Perss. } 4
\end{array}
$$

dengan:

$\mathrm{Cm}=$ koefisienapengaliran rata-rataa

$\mathrm{C}_{1}, \mathrm{C}_{2}, \ldots, \mathrm{C}_{\mathrm{n}}=$ koefisienapengaliran yangasesuai denganakondisi permukaana $\mathrm{A}_{1}, \mathrm{~A}_{2}, \ldots, \mathrm{A}_{\mathrm{n}}=$ luasadaerah pengaliranayang disesuaikanakondisi pemukaana.

\subsection{Debit Limpasan}

Rumus berikut dapat menghitung besarnya debit limpasan.

$$
\mathrm{Q}=0,00278 \text { C.I.A } \quad \text { Pers. } 5
$$


dengan:

$\mathrm{Q}=$ debit limpasan $\left(\mathrm{m}^{3} / \mathrm{dt}\right)$

$\mathrm{C}=$ koefisien pengaliran

I = intensitas hujan rerata selama waktu tiba banjir $(\mathrm{mm})$

$\mathrm{A}=$ luas daerah aliran (ha)

\subsection{Debit Air Kotor}

Air buangan merupakan air sisa yang dimanfaatkan untuk kepentingan sehari-hari. Untuk fasilitas umum, pemerintahan dan perdagangana ir buangan yang masuk ke saluran pengumpul diperkirakan sebesar 70-90\% dari kebutuhan air bersih. Rumus untuk memperkirakan jumlah debit air kotor, adalah [5]:

$$
\mathrm{Q}_{\mathrm{ak}}=\frac{P_{n} \cdot q}{A} \quad \text { Pers. } 6
$$

dengan :

$\mathrm{Q}_{\mathrm{ak}}=$ debit air kotor $\left(\mathrm{lt} / \mathrm{dtk} / \mathrm{km}^{2}\right)$

$\mathrm{P}_{\mathrm{n}} \quad=$ jumlah penduduk

$\mathrm{q} \quad=$ jumlah air buangan (lt/org/hari)

A $=$ luas daerah $\left(\mathrm{km}^{2}\right)$

\subsection{Dimensi Saluran}

Rumus Manning dapat digunakan untuk menghitung kapasitas saluran pembuang, rumus tersebut sebagai berikut:

$$
\mathrm{V}=\frac{1}{n} R^{\frac{2}{3}} S^{\frac{1}{2}} \quad \text { Pers. } 7
$$

dimana :

$\mathrm{Q}=$ kapasitas saluran $\left(\mathrm{m}^{3} / \mathrm{dt}\right)$

$\mathrm{A}=$ Luas penampang $\left(\mathrm{m}^{2}\right)$

$\mathrm{V}=$ Kecepatan aliran rata - rata $(\mathrm{m} /$ detik $)$

$\mathrm{n}=$ Koefisien kekasaran Manning

$\mathrm{R}=$ Jari-jari hidrolis $(\mathrm{m})$

$\mathrm{S}=$ kemiringan dasar saluran

\subsection{Uji Konsistensi Data Hujan}

\subsubsection{Curah Hujan Rancangan}

Dari hasil perhitungan, diketahui bahwa hanya distribusi Log Person III yang memenuhi syarat. Sehingga curah hujan rancangan yang digunakan sebagai dasar perencanaan adalah distribusi Log Person III [7].

\subsubsection{Analisa Uji Kesesuaian Distribusi}

Ada dua macam yang sering dipakai untuk menguji apakah jenis distribusi hujan rancangan dipilih sesuai dengan data yang ada, yaitu uji Chi-Square dan Smirnov Kolmogor. 
Dari perhitungan yang dilakukan, diperoleh nilai $\mathrm{X}_{\text {hitung }}=3,00$ Untuk $\alpha=5 \%$ pada tabel nilai kritis untuk uji Chi-Square diperoleh $\mathrm{X}_{c r}^{2}=5,991$. Karena $\mathrm{X}^{2}$ hitung $<\mathrm{X}^{2}{ }_{c r}$, maka hipotesanya diterima.

\subsubsection{Uji Smirnov Kol.mogorov.}

Dari perhitungan yang dilakukan, diperoleh nilai $\mathrm{D}_{\max }=0,121$. Untuk $\alpha 5 \%$ dan $\mathrm{n}$ $=10$, pada tabel nilai kritis untuk uji Smirnov-Kolmogorov didapat $\mathrm{D}_{\mathrm{cr}}=0,409$. Karena $\mathrm{D}_{\max }<\mathrm{D}_{\mathrm{cr}}$, maka distribusinya diterima.

3.9. Intensitas Hujan

Perhitungan intensitas hujan kala ulang 10 tahun sebagai berikut:

$$
I=\frac{R_{24}}{24}\left(\frac{24}{t c}\right)^{m} \quad I=\frac{141,196}{24}\left(\frac{24}{6,24}\right)^{0,667} \quad \text { Pers. } 8
$$

$\mathrm{I}=14,45 \mathrm{~mm} / \mathrm{jam}$

\subsection{Koefisien Pengaliran}

Tiap kapling rumah rata-rata $85 \%$ berupa bangunan dan $15 \%$ berupa halaman.

$$
C m=\frac{\sum_{i=1}^{n} A_{i} \cdot C_{i}}{\sum_{i=1}^{n} A_{i}}
$$

Pers. 9

Jadi C (koefisien limpasan) gabungan adalah 0,36

\subsection{Debit Air Kotor}

Perhitungan air buangan tiap penduduk didapat dari:

$\mathrm{Q}_{\mathrm{ak}}=\frac{7828 \times 0,000926}{111,07}$

$$
\mathrm{Q}_{\mathrm{ak}}=\frac{P_{n} \cdot q}{A}
$$

Pers. 10

$\mathrm{Q}_{\mathrm{ak}}=0,0002344 \mathrm{~m}^{3} / \mathrm{dtk}$

\subsection{Perhitungan Kapasitas Saluran Drainase Eksisting}

$$
\begin{array}{ll}
\text { (A) } & =\text { Dengan Pengukuran di lapangan didapat } \mathrm{h}=1,00 \mathrm{~b}=1,50 \\
\mathrm{~A} & =(\mathrm{h} . \mathrm{b}) \\
\mathrm{A} & =(1,00.1,50) \\
\mathrm{A} & =1,50 \mathrm{~m}^{2} \\
\text { (P) } & =\mathrm{b}+2 \mathrm{~h} \\
\mathrm{P} & =1,50+2.1,00 \\
\mathrm{P} & =3,5
\end{array}
$$




$$
\begin{array}{ll} 
& (\mathrm{R}) \quad=\frac{(\mathrm{b} \cdot \mathrm{h})}{\mathrm{b}+2 \mathrm{~h}} \\
\mathrm{R} & =\frac{(1,50 \cdot 1,00)}{1,50+2 \cdot(1,00)} \\
\mathrm{R} & =0,429 \\
\text { Dengan s } & =0,0026 \mathrm{n}=0,017 \\
& (\mathrm{~V}) \quad=\frac{1}{n} \cdot R^{2 / 3} \cdot \mathrm{s}^{1 / 2} \\
\mathrm{~V} & =\frac{1}{0,017} \cdot 0,429^{2 / 3} \cdot 0,0026^{1 / 2} \\
\mathrm{~V} & =1,718 \mathrm{~m} / \mathrm{s}=\mathrm{A} \cdot \mathrm{V} \\
\mathrm{Q} & (\mathrm{Q}) \quad 1,50 \cdot 1,718 \\
\mathrm{Q} & =2,577 \mathrm{~m}^{3} / \mathrm{s}
\end{array}
$$

Pers. 12

Pers. 13

Pers. 14

3.13. Perhitungan Debit Banjir Dengan Metode Rasional

$$
\begin{aligned}
& \mathrm{Q}_{\text {genangan }}=\left(\mathrm{Q}_{\text {air kotor }}+\mathrm{Q}_{\text {air hujan }}\right)-\mathrm{Q}_{\text {eksisting }} \\
& \mathrm{Q}_{\text {hujan }}=0,00278 \text {. C. I. A } \\
& \mathrm{Q}_{\text {air kotor }}=\text { Pn.q/A } \\
& \text { Qeksisting = A. V } \\
& \text { Diketahui: } \\
& \mathrm{C}=0,4 \\
& \text { I } \quad=14,45 \mathrm{~mm} / \mathrm{jam} \\
& \mathrm{A} \quad=0,978 \mathrm{ha} \\
& \mathrm{Q}_{\text {hujan }} \quad=0,00278 \text {. C. I. A } \\
& \mathrm{Q}_{\text {hujan }} \quad=0,00278.0,4.14,45.0,978 \\
& \mathrm{Q}_{\text {hujan }}=0,016 \mathrm{~m}^{3} / \text { detik }
\end{aligned}
$$

Pers. 15

Perhitungan buangan air kotor penduduk:

$$
\begin{array}{ll} 
& \text { Q }_{\text {air kotor }}=\mathrm{Pn} \cdot \mathrm{q} / \mathrm{A} \\
\mathrm{Q}_{\text {air kotor }} & =0,0002344 \mathrm{~m}^{3} / \mathrm{dtk}
\end{array}
$$

Pers. 16

Perhitungan banjir keadaan saluran eksisting:

$$
\begin{array}{cc} 
& \mathrm{Q}_{\text {genangan }}=1,1\left(\mathrm{Q}_{\text {hujan }}+\mathrm{Q}_{\text {air kotor }}\right)-\mathrm{Q}_{\text {eksisting }} \\
\mathrm{Q}_{\text {genangan }} & =1,1(2,69-2,658) \\
\mathrm{Q}_{\text {genangan }} & =0,03 \mathrm{~m}^{3} / \mathrm{dt}
\end{array}
$$

Pers. 17

3.14. Jumlah Saluran Drainase Eksisting 
Tabel 5: Kapasitas Saluran Eksisting

\begin{tabular}{|c|c|c|c|c|c|c|c|c|c|c|c|c|c|c|}
\hline \multirow{2}{*}{ No } & \multirow{2}{*}{ Nama Saluran } & \multirow{2}{*}{ Tipe saluran } & \multirow{2}{*}{$\mathrm{n}$} & \multicolumn{2}{|c|}{$\begin{array}{l}\text { Dimensi } \\
\text { Saluran } \\
\end{array}$} & \multirow{2}{*}{$\begin{array}{c}\text { A } \\
\left(\mathrm{m}^{2}\right)\end{array}$} & \multirow{2}{*}{$\mathrm{P}\left(\mathrm{m}^{2}\right)$} & \multirow{2}{*}{$\mathrm{R}$} & \multirow{2}{*}{$\mathrm{S}$} & \multirow{2}{*}{$\begin{array}{c}\mathrm{V} \\
(\mathrm{m} / \mathrm{det})\end{array}$} & \multirow{2}{*}{$\begin{array}{c}\text { Kapasitas } \\
\text { saluran } \\
\left(\mathrm{m}^{3} / \mathrm{det}\right)\end{array}$} & \multirow{2}{*}{$\begin{array}{c}\mathrm{Q} \\
\text { rencana } \\
\left(\mathrm{m}^{3} / \text { det }\right)\end{array}$} & \multirow{2}{*}{$\begin{array}{c}\mathrm{Q} \\
\underset{\left(\mathrm{m}^{3} / \mathrm{det}\right)}{ }\end{array}$} & \multirow{2}{*}{ Keterangan } \\
\hline & & & & $\begin{array}{c}\mathrm{b} \\
(\mathrm{m})\end{array}$ & $\begin{array}{c}\mathrm{h} \\
(\mathrm{m})\end{array}$ & & & & & & & & & \\
\hline 1 & Sal. Cempaka 1 & Segiempat & 0.017 & 1.50 & 1.00 & 1.50 & 3.50 & 0.429 & 0.0026 & 1.718 & 2.577 & 0.06 & -2.77 & AMAN \\
\hline 2 & Sal. Cempaka 2 & Segiempat & 0.017 & 0.65 & 0.55 & 0.36 & 1.75 & 0.204 & 0.0047 & 1.395 & 0.499 & 0.03 & -0.52 & AMAN \\
\hline 3 & Sal. Cempaka 3 & Segiempat & 0.017 & 1.50 & 1.00 & 1.50 & 3.50 & 0.429 & 0.0066 & 2.718 & 4.077 & 1.27 & -3.09 & AMAN \\
\hline 4 & Sal. Cempaka Raya & Segiempat & 0.017 & 1.60 & 0.85 & 1.36 & 3.30 & 0.412 & 0.0039 & 2.032 & 2.764 & 0.41 & -2.59 & AMAN \\
\hline 5 & Sal. Delima 1 & Segiempat & 0.017 & 0.75 & 0.50 & 0.38 & 1.75 & 0.214 & 0.0107 & 2.180 & 0.818 & 0.25 & -0.62 & AMAN \\
\hline 6 & Sal. Delima 2 & Segiempat & 0.017 & 0.62 & 0.55 & 0.34 & 1.72 & 0.198 & 0.0086 & 1.852 & 0.631 & 0.10 & -0.58 & AMAN \\
\hline 7 & Sal. Sumatra 1 & Segiempat & 0.017 & 0.75 & 0.50 & 0.38 & 1.75 & 0.214 & 0.0040 & 1.332 & 0.500 & 0.47 & -0.03 & AMAN \\
\hline 8 & Sal. Sumatra 2 & Segiempat & 0.017 & 1.00 & 0.62 & 0.62 & 2.24 & 0.277 & 0.0040 & 1.580 & 0.980 & 0.20 & -0.86 & AMAN \\
\hline 9 & Sal. Sumatara 3 & Segiempat & 0.017 & 0.85 & 0.50 & 0.43 & 1.85 & 0.230 & 0.0033 & 1.274 & 0.541 & 0.20 & -0.38 & AMAN \\
\hline 10 & Sal. Seruni 1 & Segiempat & 0.017 & 1.28 & 0.68 & 0.87 & 2.64 & 0.330 & 0.0008 & 0.808 & 0.703 & 0.03 & -0.74 & AMAN \\
\hline 11 & Sal. Slorok Raya 1A & Segiempat & 0.017 & 1.35 & 0.70 & 0.95 & 2.75 & 0.344 & 0.0101 & 2.903 & 2.744 & 0.30 & -2.69 & AMAN \\
\hline 12 & Sal. Seruni 2 & Segiempat & 0.017 & 1.52 & 0.77 & 1.17 & 3.06 & 0.382 & 0.0002 & 0.460 & 0.538 & 0.19 & -0.38 & AMAN \\
\hline 13 & Sal. Seruni 3 & Segiempat & 0.017 & 1.00 & 0.70 & 0.70 & 2.40 & 0.292 & 0.0014 & 0.965 & 0.675 & 0.35 & -0.36 & AMAN \\
\hline 14 & Sal. Seruni 4 & Segiempat & 0.017 & 1.20 & 0.70 & 0.84 & 2.60 & 0.323 & 0.0191 & 3.825 & 3.213 & 0.10 & -3.42 & AMAN \\
\hline 15 & Sal. Janur A & Segiempat & 0.017 & 0.60 & 0.52 & 0.31 & 1.64 & 0.190 & 0.0020 & 0.866 & 0.270 & 0.05 & -0.24 & AMAN \\
\hline 16 & Sal. Janur B & Segiempat & 0.017 & 1.10 & 0.72 & 0.79 & 2.54 & 0.312 & 0.0022 & 1.259 & 0.997 & 0.08 & -1.01 & AMAN \\
\hline 17 & Sal. Janur C & Segiempat & 0.017 & 1.92 & 0.88 & 1.68 & 3.67 & 0.458 & 0.0005 & 0.782 & 1.317 & 0.64 & -0.74 & AMAN \\
\hline 18 & Sal. Slorok I & Segiempat & 0.017 & 2.17 & 1.05 & 2.28 & 4.27 & 0.534 & 0.0024 & 1.883 & 4.290 & 1.12 & -3.49 & AMAN \\
\hline 19 & Sal. Slorok II & Segiempat & 0.017 & 1.00 & 0.76 & 0.76 & 2.52 & 0.302 & 0.0048 & 1.837 & 1.396 & 0.99 & -0.45 & AMAN \\
\hline 20 & Sal. Slorok III & Segiempat & 0.017 & 0.77 & 0.62 & 0.48 & 2.01 & 0.238 & 0.0138 & 2.653 & 1.267 & 0.38 & -0.97 & AMAN \\
\hline 21 & Sal. Slorok IV & Segiempat & 0.017 & 1.00 & 0.57 & 0.57 & 2.14 & 0.266 & 0.0162 & 3.101 & 1.768 & 1.79 & 0.03 & MELIMPAS \\
\hline 22 & Sal. Slorok V & Segiempat & 0.017 & 1.00 & 0.65 & 0.65 & 2.30 & 0.283 & 0.0103 & 2.571 & 1.671 & 1.66 & -0.01 & AMAN \\
\hline 23 & Sal. Slorok VI & Segiempat & 0.017 & 0.67 & 0.55 & 0.37 & 1.77 & 0.208 & 0.0502 & 4.631 & 1.707 & 0.53 & -1.29 & AMAN \\
\hline 24 & Sal. Mertoyudo 1 & Segiempat & 0.017 & 1.00 & 0.60 & 0.60 & 2.20 & 0.273 & 0.0325 & 4.461 & 2.677 & 1.19 & -1.63 & AMAN \\
\hline 25 & Sal. Mertoyudo 2 & Segiempat & 0.017 & 0.66 & 0.50 & 0.33 & 1.66 & 0.199 & 0.0199 & 2.826 & 0.933 & 0.92 & -0.01 & AMAN \\
\hline 26 & Sal. Mertoyudo 3 & Segiempat & 0.017 & 0.74 & 0.58 & 0.43 & 1.90 & 0.226 & 0.0278 & 3.639 & 1.562 & 0.21 & -1.49 & AMAN \\
\hline 27 & Sal. Mertoyudo 4 & Segiempat & 0.017 & 0.85 & 0.62 & 0.53 & 2.09 & 0.252 & 0.0034 & 1.371 & 0.722 & 0.45 & -0.30 & AMAN \\
\hline 28 & Sal. Mertoyudo 5 & Segiempat & 0.017 & 1.00 & 0.60 & 0.60 & 2.20 & 0.273 & 0.0036 & 1.493 & 0.896 & 0.90 & 0.01 & MELIMPAS \\
\hline 29 & Sal. Mertoyudo 6 & Segiempat & 0.017 & 0.50 & 0.50 & 0.25 & 1.50 & 0.167 & 0.0287 & 3.017 & 0.754 & 0.76 & 0.01 & MELIMPAS \\
\hline 30 & Sal. Mertoyudo 7 & Segiempat & 0.017 & 0.78 & 0.60 & 0.47 & 1.98 & 0.236 & 0.0043 & 1.476 & 0.691 & 0.25 & -0.48 & AMAN \\
\hline 31 & Sal. Slorok Raya 1 & Segiempat & 0.017 & 2.50 & 2.15 & 5.38 & 6.80 & 0.790 & 0.0004 & 0.954 & 5.129 & 5.27 & 0.15 & MELIMPAS \\
\hline 32 & Sal. Slorok Raya 2 & Segiempat & 0.017 & 1.00 & 1.20 & 1.20 & 3.40 & 0.353 & 0.0103 & 2.976 & 3.571 & 3.60 & 0.04 & MELIMPAS \\
\hline 33 & Sal. Slorok Raya 3 & Segiempat & 0.017 & 1.00 & 1.00 & 1.00 & 3.00 & 0.333 & 0.0131 & 3.240 & 3.240 & 3.44 & 0.22 & MELIMPAS \\
\hline 34 & Sal. Slorok Raya 4 & Segiempat & 0.017 & 1.00 & 1.20 & 1.20 & 3.40 & 0.353 & 0.0067 & 2.404 & 2.885 & 2.91 & 0.03 & MELIMPAS \\
\hline
\end{tabular}




\begin{tabular}{|c|c|c|c|c|c|c|c|c|c|c|c|c|c|c|}
\hline \multirow{2}{*}{ No } & \multirow{2}{*}{ Nama Saluran } & \multirow{2}{*}{ Tipe saluran } & \multirow{2}{*}{$\mathrm{n}$} & \multicolumn{2}{|c|}{$\begin{array}{c}\text { Dimensi } \\
\text { Saluran } \\
\end{array}$} & \multirow{2}{*}{$\begin{array}{c}\text { A } \\
\left(\mathrm{m}^{2}\right)\end{array}$} & \multirow{2}{*}{$\mathrm{P}\left(\mathrm{m}^{2}\right)$} & \multirow{2}{*}{$\mathrm{R}$} & \multirow{2}{*}{ S } & \multirow{2}{*}{$\begin{array}{c}\mathrm{V} \\
(\mathrm{m} / \mathrm{det})\end{array}$} & \multirow{2}{*}{$\begin{array}{c}\text { Kapasitas } \\
\text { saluran } \\
\left(\mathrm{m}^{3} / \mathrm{det}\right)\end{array}$} & \multirow{2}{*}{$\begin{array}{c}\mathrm{Q} \\
\text { rencana } \\
\left(\mathrm{m}^{3} / \mathrm{det}\right)\end{array}$} & \multirow{2}{*}{$\begin{array}{c}\mathrm{Q} \\
\underset{\left(\mathrm{m}^{3} / \mathrm{det}\right)}{\operatorname{limpan}}\end{array}$} & \multirow{2}{*}{ Keterangan } \\
\hline & & & & $\begin{array}{c}\mathrm{b} \\
(\mathrm{m})\end{array}$ & $\begin{array}{c}\mathrm{h} \\
(\mathrm{m})\end{array}$ & & & & & & & & & \\
\hline 35 & Sal. Raya Nusantara 1 & Segiempat & 0.017 & 1.00 & 0.50 & 0.50 & 2.00 & 0.250 & 0.0074 & 2.005 & 1.003 & 0.39 & -0.67 & AMAN \\
\hline 36 & Sal. Raya Nusantara 2 & Segiempat & 0.017 & 1.10 & 0.72 & 0.79 & 2.54 & 0.312 & 0.0026 & 1.378 & 1.091 & 0.72 & -0.41 & AMAN \\
\hline 37 & Sal. Raya Nusantara 3 & Segiempat & 0.017 & 1.25 & 0.75 & 0.94 & 2.75 & 0.341 & 0.0019 & 1.254 & 1.176 & 0.94 & -0.26 & AMAN \\
\hline 38 & Kali Slorok & Segiempat & 0.017 & 5.00 & 2.50 & 12.50 & 10.00 & 1.250 & 0.0013 & 2.507 & 31.337 & 5.68 & -28.23 & AMAN \\
\hline 39 & Kali Garum & Segiempat & 0.017 & 4.50 & 2.30 & 10.35 & 9.10 & 1.137 & 0.0019 & 2.767 & 28.642 & 0.49 & -30.97 & AMAN \\
\hline
\end{tabular}

Sumber: Perhitungan

Dari perhitungan kapasitas saluran eksisting tersebut terdapat 7 (tujuh) saluran drainase yang melimpas yaitu, Saluran Slorok IV, Saluran Mertoyudo 5, Saluran Mertoyudo 6, Saluran Slorok Raya 1, Saluran Slorok Raya 2, Saluran Slorok Raya 3 dan Saluran Slorok Raya 4

Tabel 6: Saluran Yang Melimpas

\begin{tabular}{|c|c|c|c|c|c|c|c|c|c|c|c|c|c|c|}
\hline \multirow{2}{*}{ No } & \multirow{2}{*}{ Nama Saluran } & \multirow{2}{*}{ Tipe saluran } & \multirow{2}{*}{$\mathrm{n}$} & \multicolumn{2}{|c|}{$\begin{array}{l}\text { Dimensi } \\
\text { Saluran }\end{array}$} & \multirow{2}{*}{$\begin{array}{c}\text { A } \\
\left(m^{2}\right)\end{array}$} & \multirow{2}{*}{$\mathrm{P}\left(\mathrm{m}^{2}\right)$} & \multirow{2}{*}{$\mathrm{R}$} & \multirow{2}{*}{$\mathrm{S}$} & \multirow{2}{*}{$\begin{array}{c}\mathrm{V} \\
(\mathrm{m} / \mathrm{det})\end{array}$} & \multirow{2}{*}{$\begin{array}{c}\text { Kapasitas } \\
\text { saluran } \\
\left(\mathrm{m}^{3} / \mathrm{det}\right)\end{array}$} & \multirow{2}{*}{$\begin{array}{c}\mathrm{Q} \\
\text { rencana } \\
\left(\mathrm{m}^{3} / \mathrm{det}\right)\end{array}$} & \multirow{2}{*}{$\underset{\substack{\mathrm{Q} \\
\left(\mathrm{m}^{3} / \mathrm{det}\right)}}{\operatorname{limasan}}$} & \multirow{2}{*}{ Keterangan } \\
\hline & & & & $\begin{array}{c}\mathrm{b} \\
(\mathrm{m})\end{array}$ & $\begin{array}{c}\mathrm{h} \\
(\mathrm{m})\end{array}$ & & & & & & & & & \\
\hline 1 & Sal. Slorok IV & Segiempat & 0.017 & 1.00 & 0.57 & 0.57 & 2.14 & 0.266 & 0.0162 & 3.101 & 1.768 & 1.79 & 0.03 & MELIMPAS \\
\hline 2 & Sal. Mertoyudo 5 & Segiempat & 0.017 & 1.00 & 0.60 & 0.60 & 2.20 & 0.273 & 0.0036 & 1.493 & 0.896 & 0.90 & 0.01 & MELIMPAS \\
\hline 3 & Sal. Mertoyudo 6 & Segiempat & 0.017 & 0.50 & 0.50 & 0.25 & 1.50 & 0.167 & 0.0287 & 3.017 & 0.754 & 0.76 & 0.01 & MELIMPAS \\
\hline 4 & Sal. Slorok Raya 1 & Segiempat & 0.017 & 2.50 & 2.15 & 5.38 & 6.80 & 0.790 & 0.0004 & 0.954 & 5.129 & 5.27 & 0.15 & MELIMPAS \\
\hline 5 & Sal. Slorok Raya 2 & Segiempat & 0.017 & 1.00 & 1.20 & 1.20 & 3.40 & 0.353 & 0.0103 & 2.976 & 3.571 & 3.60 & 0.04 & MELIMPAS \\
\hline 6 & Sal. Slorok Raya 3 & Segiempat & 0.017 & 1.00 & 1.00 & 1.00 & 3.00 & 0.333 & 0.0131 & 3.240 & 3.240 & 3.44 & 0.22 & MELIMPAS \\
\hline 7 & Sal. Slorok Raya 4 & Segiempat & 0.017 & 1.00 & 1.20 & 1.20 & 3.40 & 0.353 & 0.0067 & 2.404 & 2.885 & 2.91 & 0.03 & MELIMPAS \\
\hline
\end{tabular}

Sumber: Hasil perhitungan

\subsection{Perhitungan Sumur resapan}

Konsep awal sumur resapan yaitu sebagai pengganti tanah resapan air hujan yang mengalami perkerasan yang menyebabkan air hujan yang jatuh tidak dapat langsung meresap ke dalam tanah [8].

\subsubsection{Menghitung Kapasitas Sumur Resapan [9].}

Maka:

$\mathrm{V}_{\text {sumur }}=1 / 4 . \pi . \mathrm{D}^{2} . \mathrm{H}$

$\mathrm{V}_{\text {sumur }}=1 / 4 \cdot \pi \cdot 1,2^{2} \cdot 2,4$

Pers. 18

$\mathrm{V}_{\text {sumur }}=2,713 \mathrm{~m}^{3}$

\subsubsection{Menghitung debit resap}

Maka:

Qresap sumur = F.K.H

Qresap sumur $=2,4 \cdot 2,16 \cdot 10^{-5} \cdot 2,4$

Pers. 19

Qresap sumur $=0,000124 \mathrm{~m}^{3} /$ detik 


\subsubsection{Menghitung Debit Sumur}

Maka:

Pers. 20

$Q_{\text {sumur }}=\frac{F \cdot K \cdot H}{1-e^{\left(-\frac{F \cdot K \cdot T}{\pi \cdot R^{2}}\right)}} \quad Q_{\text {sumur }}=\frac{2,4.0,0000216.2,4}{1-2,718^{\left(-\frac{2,4.0,0000216.17200}{3,14 \cdot 0,5^{2}}\right)}}$

$Q_{\text {sumur }}=0,00087 \quad \mathrm{~m}^{3} /$ detik

3.15.4. Menghitung Waktu Pengisian Sumur dan Waktu Resap

Maka:

$\mathrm{t}_{\text {sumur }} \quad=\mathrm{V}_{\text {sumur }} / \mathrm{Q}_{\text {sumur }}$

$\mathrm{t}_{\text {sumur }} \quad=2,713 / 0,00087$

Pers. 21

$\mathrm{t}_{\text {sumur }} \quad=3101,85$ detik

Maka:

$\mathrm{t}_{\text {resap }} \quad=\mathrm{V}_{\text {sumur }} / \mathrm{Q}_{\text {resap sumur }}$

Pers. 22

$\mathrm{t}_{\text {resap }} \quad=2,713 / 0,000124$

$\mathrm{t}_{\text {resap }} \quad=21805,56$ detik

3.15.5. Menghitung Jumlah Sumur Yang dibutuhkan

Maka:

$\begin{array}{ll}\mathrm{n}=\frac{\text { Qtotal }}{\text { Qsumur }} & \text { Pers. } 23\end{array}$

$\mathrm{n}=\frac{0,027}{0,00087}$

$\mathrm{n}=30,89$ dibulatkan menjadi 31 sumur

3.15.6. Menghitung Volume Reduksi Genangan akibat Limpasan

3.15.6.1. Sebelum adanya sumur resapan

Maka:

$\mathrm{V}=\mathrm{Q}_{\text {total. }} \mathrm{T}$

$\mathrm{V}=0,027 \cdot 3600$

Pers. 24

$\mathrm{V} \quad=97,259 \mathrm{~m}^{3}$

$\mathrm{H} \quad=\frac{V}{A}$

$\mathrm{H} \quad=\frac{97,259}{13,644}$

$\mathrm{H}=7,128 \mathrm{~m}$

3.15.6.2. Setelah adanya sumur Resapan [10].

Maka:

pers. 25

$\mathrm{V}=\mathrm{Q}_{\text {limpasan. }} \mathrm{t}$

$\mathrm{V}=-0,00010.3600$

$\mathrm{V}=-0,349 \mathrm{~m}^{3}=0 \mathrm{~m}^{3}$ (tidak ada limpasan)

$\mathrm{H} \quad=\quad V$

$$
\bar{A}
$$




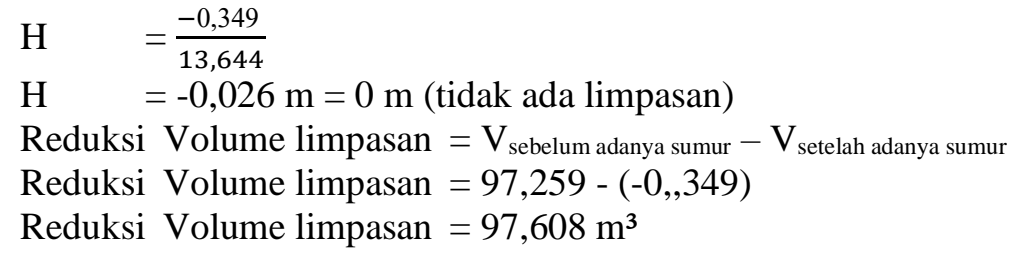

Tabel 7. Perhitungan Reduksi Limpasan

\begin{tabular}{|c|c|c|c|c|c|c|c|}
\hline No & Nama Saluran & $\begin{array}{l}\text { V volume limpasan } \\
\text { sebelum ada } \\
\text { sumur }\end{array}$ & $\begin{array}{l}\text { H tinggi limpasan } \\
\text { sebelum ada } \\
\text { sumur }\end{array}$ & $\begin{array}{l}\text { Q limpasan } \\
\text { sesudah ada } \\
\text { sumur }\end{array}$ & $\begin{array}{c}\text { V volume limpasan } \\
\text { sesudah ada } \\
\text { sumur }\end{array}$ & $\begin{array}{l}\text { H tinggi limpasan } \\
\text { sesudah ada } \\
\text { sumur }\end{array}$ & $\begin{array}{l}\text { Reduksi } \\
\text { Volume } \\
\text { limpasan }\end{array}$ \\
\hline & & $\left(\mathrm{m}^{3}\right)$ & $(\mathrm{m})$ & $\left(\mathrm{m}^{3} /\right.$ detik $)$ & $\left(\mathrm{m}^{3}\right)$ & (m) & $\left(\mathrm{m}^{3}\right)$ \\
\hline 1 & Sal. Slorok IV & 97.259 & 7.128 & -0.00010 & -0.349 & -0.026 & 97.608 \\
\hline 2 & Sal. Mertoyudo 5 & 22.401 & 1.642 & -0.00077 & -2.788 & -0.204 & 25.189 \\
\hline 3 & Sal. Mertoyudo 6 & 28.694 & 8.255 & -0.00078 & -2.793 & -0.291 & 31.487 \\
\hline 4 & Sal. Slorok Raya 1 & 229.680 & 66.074 & -0.00005 & -0.172 & -0.049 & 229.852 \\
\hline 5 & Sal. Slorok Raya 2 & 133.057 & 9.453 & -0.00065 & -2.335 & -0.166 & 135.392 \\
\hline 6 & Sal. Slorok Raya 3 & 80.640 & 5.729 & -0.00034 & -1.225 & -0.087 & 81.865 \\
\hline 7 & Sal. Slorok Raya 4 & 113.227 & 7.171 & -0.00003 & -0.124 & -0.008 & 113.352 \\
\hline
\end{tabular}

Sumber: Hasil Perhitungan

\section{Kesimpulan dan Saran}

\section{1. kesimpulan}

Berdasarkan analisis sera hasil perhitungan yang sudah dilakukan, maka kesimpulan yang dapat diambil adalah:

1. Debit rancangan total pada Kali Slorok dari hasil analisa dengan kala ulang 10 tahun yang didapat dari debit air hujan sebesar $21,82 \mathrm{~m}^{3} /$ detik dan sebesar $2,37 \mathrm{~m}^{3} /$ detik $=24,19$ $\mathrm{m}^{3} /$ detik pada Kali Garum

2. Dari hasil evaluasi kapasitas saluran drainase di daerah studi diketahui dari 37 (tiga puluh tujuh) saluran terdapat 7 (tujuh) saluran yang tidak dapat menampung debit banjir rancangan dengan kala ulang 10atahun.

3. Untuk mencegah terjadinya genangan di daerah studi, maka direncanakan beberapa alternatif sebagai berikut:

a. Alternatif 1 : Memperdalam dimensi saluran drainase. Dari hasil perhitungan saluran maka perlu direncanakan penambahan kedalaman saluran sekitar 0,6 m

b. Alternatif 2 : Merencanakan pembuatan sumur resapan. Dari hasil perhitungan saluran yang tidak dapat menampung debit rencana maka ditentukan dimensi untuk sumur resapan adalah diameter 1,20 $\mathrm{m}$ dan tinggi 2,40 m. Jumlah sumur yang di butuhkan pada saluran drainase Slorok IV sebanyak 31 buah, Mertoyudo 5 sebanyak 8 buah, 
Mertoyudo 6 sebanyak 10 buah, Slorok Raya 1 sebanyak 73 buah, Slorok Raya 2 sebanyak 43 buah, Slorok Raya 3 sebanyak 26 buah, Slorok Raya 4 sebanyak 36 buah.

c. Alternatif 3 : Merubah dimensi saluran dan menambahkan perencanaan sumur resapan. Mengalirkan air melalui saluran dengan $70 \%$ dari debit limpasan dan sisanya $30 \%$ direduksi oleh sumur resapan.

\subsection{Saran}

Berdasarkan pada studi yang telah dilakukan, maka penyusun dapat menyarankan beberapa masukan sebagai berikut:

1. Perlunya kesadaran dari masyarakat dan instansi sekitarnya agar memelihara saluran drainase dan pelengkapnya secara berkal supaya saluran dapat berfungsi dengan baik.

2. Dari tiga alternatif yang direncanakan untuk mengatasi genangan yang ada di Desa Slorok, merehabilitasi dengan memperdalam saluran dan adanya perencanaan sumur resapan lebih disarankan agar lebih efisien dan untuk menjaga konservasi air tanah di daerah Desa Slorok.

\section{Daftar Pustaka}

[1] Maknun, Dillon Asmara (2016). Studi Evaluasi dan Perencanaan Sistem Drainase di Kecamatan Driyorejo Kabupaten Gresik (Studi Kasus Desa Randegansari Kecamatan Driyorejo Kabupaten Gresik. Malang: Tidak dipublikasikan

[2]Januar, Lalu Satria. (2017). Studi Evaluasi Jaringan Drainase Daerah Jati Pinggir Petamburan di Wilayah Banjir Kanal Barat Provinsi DKI Jakarta. Malang: Tidak dipublikasikan

[3] Limantara, Lily Montarcih. (2009). Hidrologi Praktis. Bandung : Lubuk Agung.

[4] Suripin. (2003). Sistem Drainasi Perkotaan Yang Berkelanjutan. Yogyakarta : Penerbit Andi.

[5] Suhardjono. (2013). Naskah Buku Ajar Drainase perkotaan. Malang: Universitas Brawijaya

[6] Suhardjono. (1984). Drainase. Malang: Fakultas teknik Universitas Brawijaya.

[7] Sri Harto. (1993). Analisa Hidrologi. Jakarta: Erlangga.

[8] Kusnaedi, (2000). Sumur Resapan Untuk Pemukiman Perkotaan dan Pedesaan. Jakarta: PT. Penebar Swadaya.

[9]Departemen Pekerjaan Umum. (1990). Tata Cara Perencanaan Umum Drainase Perkotaan. Jakarta: Yayasan Badan Penerbit Pekerjaan Umum.

[10]Departmen Pekerjaan Umum. (1991). Spesifikasi Sumur Resapan Air Hujan Untuk Lahan Pekarangan. Jakarta: SK SNI 03-2459-1991 Puslitbang. 